\title{
Effect of Skidding Operation on Organic Carbon of Forest Soil
}

\author{
Mehran Nasiri ${ }^{1}$, Majid Lotfalian ${ }^{1} \&$ Ehsan Taheri $^{2}$ \\ ${ }^{1}$ Department of Forest engineering, Sari Agricultural Sciences and Natural Resources University, Sari, Iran \\ ${ }^{2}$ Department of Chemistry and Chemical Engineering, Malek-Ashtar University of Technology (MUT), Lavizan, \\ Iran \\ Correspondence: Mehran Nasiri, Department of Forest engineering, Faculty of Natural Resources, Sari \\ Agricultural Sciences and Natural Resources University, P. O. Box 737, Sari, Mazandaran, Iran. E-mail: \\ Me.nasiri@sanru.ac.ir
}

Received: April 2, 2012 Accepted: May 30, 2012 Online Published: June 7, 2012

doi:10.5539/ijb.v4n3p13 URL: http://dx.doi.org/10.5539/ijb.v4n3p13

\begin{abstract}
According to the importance of soil in forest ecosystem, this study was conducted in Mazandaran Province of Iran to investigate the effects of skidding operation on organic carbon of soil. Therefore, the objective of this research was to compare the rate of soil organic carbon between two areas inside and outside of the skid trails based on its depth. In order to carrying out of field survey, two samples from inside (for different depth of 0-5 and 5-10 centimeters) and two samples from outside of each 20 meters of skid trail were taken (Totally 80 soil sample). The rate of organic carbon was determined with burning through black\&walking method. Results show that in all stations the percentage of organic carbon in soil samples collected from outside of trails was more than that of soil samples collected from inside of skid trail. Result of statistical analysis show that the skidding causes to significant difference between the two treatments for percentage of organic carbon (inside and outside of skid trail) in different depth of soil $(\mathrm{P}<0.05)$. Moreover, changes in percentage of soil organic carbon in samples measured for inside of skid trail was high and for outside of skid trail was low. The mean of soil organic carbon in layer of 0-5 centimeter was more than that of the layer of 5-10 centimeter. But, this difference is not significant $(\mathrm{P}<0.05)$. In order to decrease damage to forest soil it is better that the skid trail is covered by vegetation foliage and wood debris. Moreover, it is recommended that the skid trails seeded after skidding operation. Moreover, in order to decrease disturbance of soil organic matter in forest ecosystem, Tite Pressure Control System (TPCS) can be used on skidders to reduce the pressure of wheels per unit area at minimum level.
\end{abstract}

Keywords: forest soil, skidd trail, organic carbon, soil depth, pressure control system

\section{Introduction}

Forest utilization is a type of timber logging which is conducted according to scientific, technical and environmental standards. Besides, forest utilization must be based on socio-economic manuals. One of the main problems of Harvesting is damage to forest soil. In managing natural soil factors, the maintenance of organic matter in forest soils should be a long-term management aim (Greacen \& Sands, 1980). A harvesting system refers to the tools, equipment and machines used to harvest an area, while harvesting method refers to the form in which wood is delivered to the logging access road, and depends on the amount of processing. Two harvesting systems are practiced in Iran: ground based skidding system and cable system (high-lead and teleferic). The main system for wood extraction in the Hyrcanian forests is based on ground skidding by skidder.

Brown soils are the most abundant soils in the Hyrcanian forests and comprise approximately $90 \%$ of the Hyrcanian region. These are semi-deep soils found on mild slopes and include calcareous, forest acidic, podzolic and non-podzolic soils. Forestry activities can lead to soil disturbances that include compaction, rutting, and soil displacement (e.g. mineral soil exposure, erosion, and organic matter reduction). The susceptibility of soils to compaction is related to its organic matter (OM) content. The degree of OM loss and soil compaction from the forest floor directly influences the weathering rates of minerals, nutrient mineralization rates and, consequently, plant growth rates (Arocena, 2000; Hendrickson et al., 1989; Zabowski et al., 1994; Matsuura et al., 1992).

Forest harvesting has been found to decrease soil evapotranspiration, increase soil temperature and diurnal fluctuations in soil temperature and create a large amount of debris and dead roots that are easily decomposed by soil biota (Greacan \& Sands, 1980; Lenhard, 1986; Williamson \& Neilsen, 2003; Mariani et al., 2006). The 
extent of disturbances resulting from ground based timber harvesting systems varies with factors such as the slope and terrain, timber harvesting machines, methods of designating skid routs, and harvesting seasons. Ground-based skidding may result in soil penetration resistance and other structural changes in the soil that influence soil water retention and reduce soil aeration, drainage, and root penetration (Froehlich et al., 1979).

Several studies have documented the changes of exchangeable soil cations after harvesting. A study of the effect of mechanized harvesting on organic soils in North Carolina (Hassan, 1978), showed that the root mat layer (contained mostly in the upper $10 \mathrm{~cm}$ of organic soil) was compressed by 65 percent, indicating that this layer acted as a mat and supported most of the vehicle weight. Holman et al. (1978) stated that the depth of organic matter decreased along skid trails. In forest soils, undecomposed organic matter accumulates on the soil surface. This surface layer, along with woody slash material and other debris on the forest floor, has the effect of protecting the surface from the effects of the heavy machinery. Johnson et al. (1979) found that even thin leaf litter layers had the effect of reducing compaction: the penetration resistance within the wheel track of a harvest skidder was $104 \mathrm{kPa}$ in the absence of leaf cover, but only $80 \mathrm{kPa}$ below a surface layer of leaf litter.

According to the importance of soil in forest ecosystem, this study was conducted in Mazandaran Province of Iran to investigate the effects of skidding operation on organic carbon of soil. Therefore, the objective of this research was to compare the rate of soil organic carbon between two areas inside and outside of the skid trails based on its depth.

\section{Materials and Methods}

\subsection{Description of the Study Area}

Pashakola forest is located south of the city of Savadkooh in Mazandaran province, Iran (Figure 1). Large areas of these forest are located on steep to very steep slopes with an average altitude greater than $1000 \mathrm{~m}$ above sea level. The main system for wood extraction in the Pashakola forest is based on ground skidding by Timberjack $450 \mathrm{C}$ and HSM.

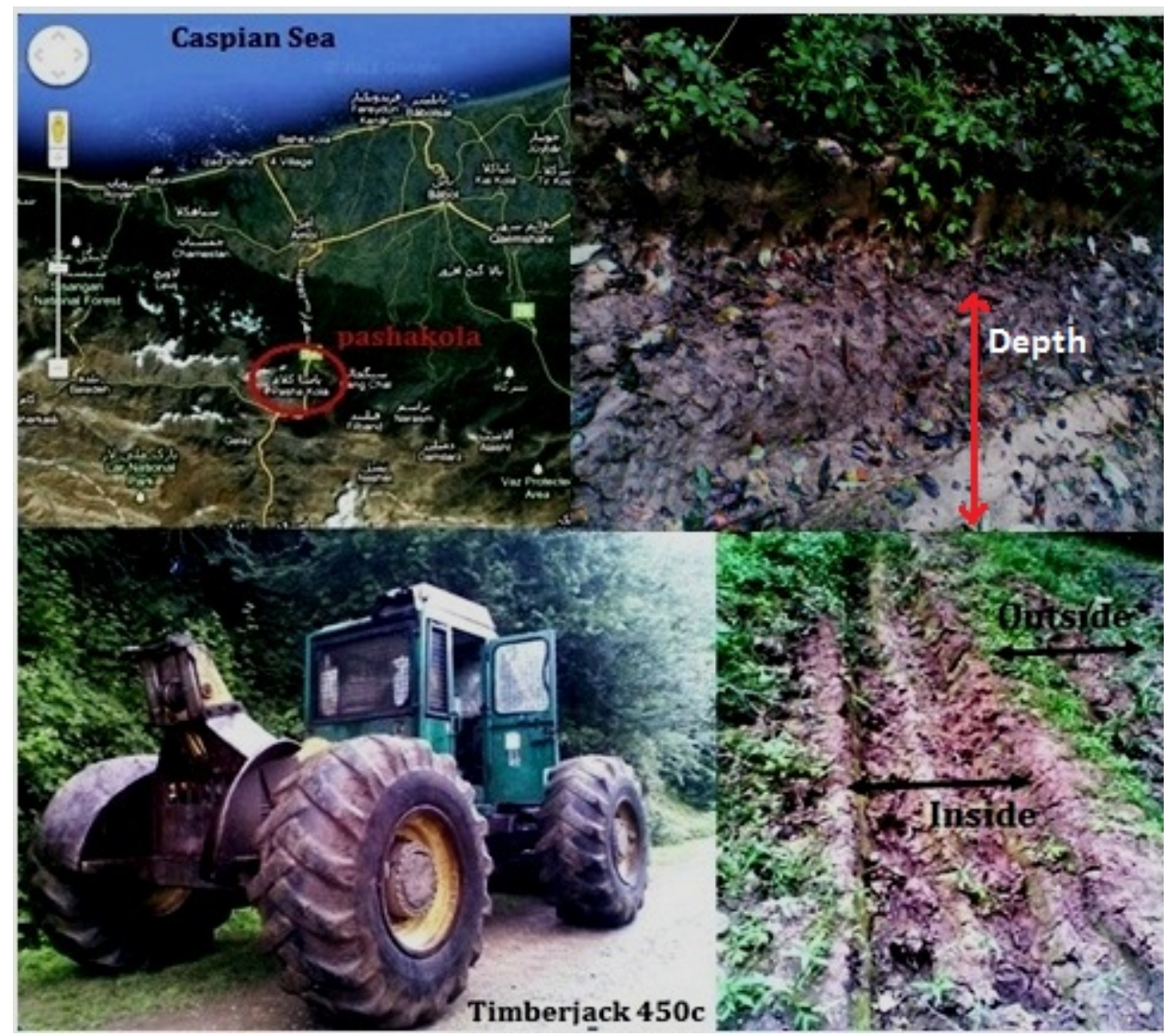

Figure 1. Map and Geographical location of the study area and Skidding operation 
In order to carrying out of field survey, two samples from inside (for different depth of 0-5 and 5-10 centimeters) and two samples from outside of each 20 meters of skid trail were taken (Totally 80 soil sample). Soil samples were transported to soil laboratory after field survey. The rate of organic carbon was determined with burning through black\&walking method. At first the some soil was compacted in mortar. Then $1 \mathrm{~g}$ soil was shed in Erlen maier $250 \mathrm{cc}$ and $10 \mathrm{cc}$ kcro was added to it. $20 \mathrm{cc}$ concentrated HSO was added to Erlen under the controlled condition (because of the Acid vapor and $\mathrm{CO}_{2}$ ).

$$
\begin{gathered}
\text { 1gr 250cc }+10 c c \text { kero } 1 \mathrm{~N}+20 \mathrm{cc} \mathrm{HSO} \mathrm{96 \%} \\
\mathrm{C}+\mathrm{K}_{2} \mathrm{Cr}_{2} \mathrm{O}_{7}+\mathrm{H}_{2} \mathrm{SO}_{4} \Rightarrow \mathrm{KSO}_{4}+\mathrm{Cr}_{2}\left(\mathrm{SO}_{4}\right)_{3}+\mathrm{CO}_{2}+\mathrm{H}_{2} \mathrm{O}
\end{gathered}
$$

The Erlen was heated on heater for 20 minute. It is note that the temperature not to be more than $165{ }^{\circ} \mathrm{C}$. The sample is taken from the heater and then must be stayed to be cool. 100 to $150 \mathrm{cc}$ sterile water is added to the sample. The titration is done using sulfate ammonium. The consumed sulfate ammonium is calculated after its color change to green slush. Finally the rate of organic matter is calculated from organic carbon.

\subsection{Data Analysis}

Completely Randomized Design was used as for the analysis of the experiments in this study and the data were analyzed using SPSS program. The effects of skidding operation on the rate organic carbon of forest soil (Inside and outside of skidd routs) were investigated using ANOVA test.

\section{Results and Discussion}

Forest harvesting is a chain of several components which is done to access sustainable harvesting with especial system. Indeed, the purposes of forest harvesting are to do plans and operations which are applicable, acceptable and safety in viewpoint of economic and environmental aspects. The soil disturbance is defined as sudden changes in physical, chemical and biological properties. Soil disturbance refers to a change in the natural state of a soil caused by an artificially imposed force. For the purpose of this research, forest soil disturbance can be broken down into three categories: compaction, rutting and soil displacement. In forestry, compaction can occur as a result of the movement of equipment over the soil. Compaction effects can also occur naturally in soils over longer periods as a result of settlement and slumping, especially at high water contents (Soane, 1990). Soil rutting occurs when the downward pressure exerted on the wet soil exceeds its shear strength and causes failure. As the water content of a soil approaches saturation, compactibility decreases, because the air spaces are filled with water, but the potential for rutting increases. Soil displacement is the mechanical movement of soil or forest floor materials by equipment and movement of logs. It involves excavation, scalping, exposure of underlying material and burial of surface soils.

These three mentioned factors have important effect on change of the organic carbon. Indeed, skidder traffic on skid trail causes to compact, rutting and displace soil. As results show that in all stations the percentage of organic carbon in soil samples collected from outside of trails was more than that of soil samples collected from inside of skid trail. Result of statistical analysis show that the skidding causes to significant difference between the two treatments for percentage of organic carbon (inside and outside of skid trail) in different depth of soil (Table 1). Moreover, changes in percentage of soil organic carbon in samples measured for inside of skid trail was high and for outside of skid trail was low (Figure 2). The variation for samples measured inside the trails was very high. This difference is due to disturbances and compaction of the surface layer of soil inside the skid trails. Similar results were observed in Demir et al. (2010) findings. They studied the organic carbon of soil in depth of 0-5 and 5-10 centimeters inside and outside of the skid trail.

Davis (1992) conducted a research in USA and indicated that the surface layer of forest especially in first 4 centimeters (soil organic carbon) the soil has been compacted 20\% more than other depth. Magnusson et al. (1999) in a research reported that the rate of increasing soil compaction in clear cut and full length tree system was $15 \%$ in first 20 centimeter of soil. They concluded that the compaction in this layer causes to disturbance in rate of soil organic matter. Results show that the increasing soil depth has not significant effect on percentage of soil organic carbon (Table 1). As mentioned in previous the reason of these variations inside the skid trails is due to soil disturbances. The rubber tired skidders are heavy machines and have lower impact area as compared to wheel chained machines. So, more pressure and disturbances are inserted to soil from these machines. Wiliam and Nilsson (2000) reported that timber logging using the skidders causes to increase 0.17 of soil bulk density and remove organic matter in surface layer of soil. 62 percent of soil compaction was occurred in first 10 centimeter of soil and in first traffic due to heavy weight of machine. 


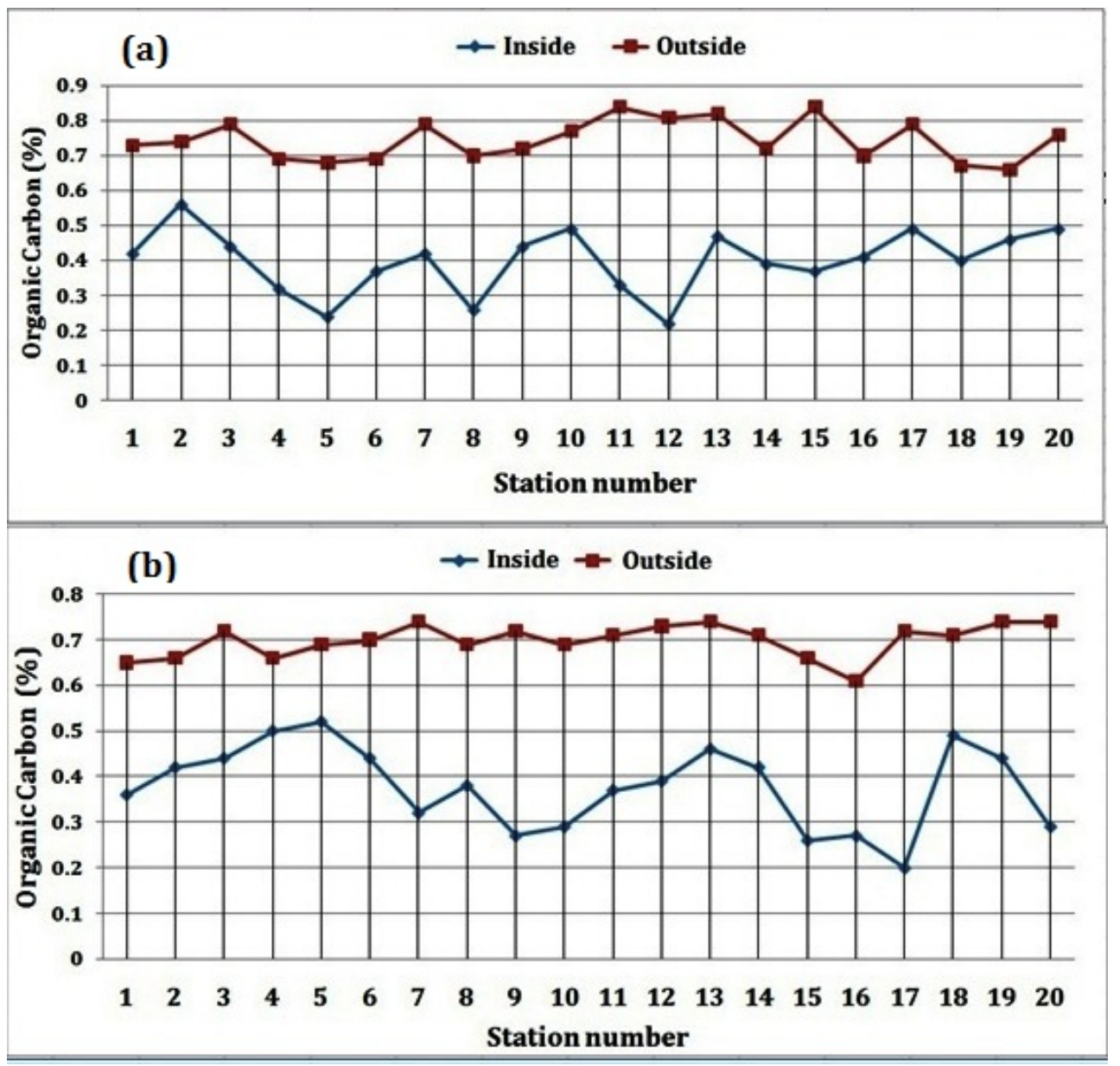

Figure 2. Comparision of organic carbon in the inside and outside of skidding routs; (a) : 0-5 depth of soil; (b): 5-10 depth of soil

Results of this study showed that different soil depth (0-5 and 5-10 centimeters) has not significant effect on soil organic matter (Figure 3). The result of statistical analysis showed that there wasn't significant difference among treatments (Table 1). Demir et al. (2010) studied the nutrients of soil in Turkish forests. Results showed that there wasn't significant difference between the depth of 0-5 and 5-10 centimeter for the organic carbon. This was due to washing (migration of organic matter to deep layer of soil) and vicinity of these layers. According to Figure 3 it was demonstrated that the mean of soil organic carbon in layer of 0-5 centimeter was more than that of the layer of 5-10 centimeter. But, this difference is not significant $(\mathrm{P}<0.05)$.

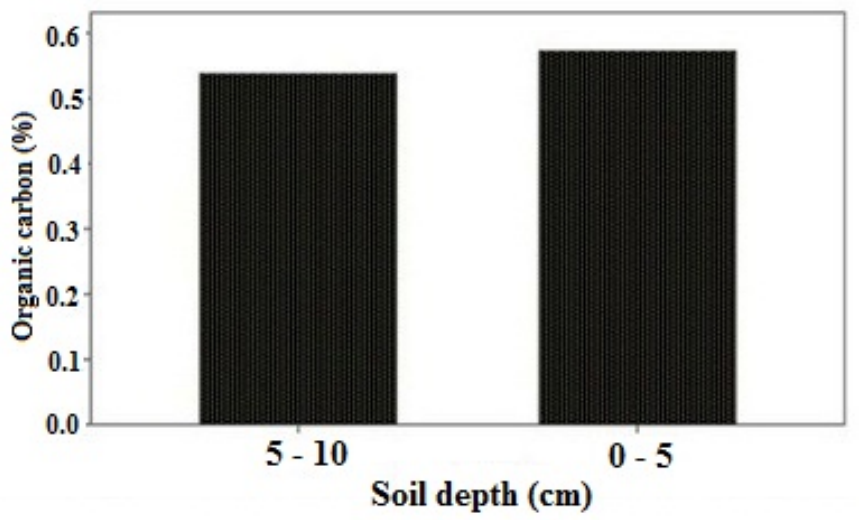

Figure 3. Comparision of organic carbon in different depth of soil 
Table 1. ANOVA for statistically comparsion of organic carbon between inside and outside of skidding routs

\begin{tabular}{ccccccc}
\hline Treatment & & DF & SS & MS & F & sig \\
\hline Inside \& outside & B & 1 & 1.197 & 1.197 & $209.84^{*}$ & 0.0 \\
(depth 0-5cm) & W & 38 & 0.217 & 0.06 & & \\
Inside \& outside & B & 1 & 1.04 & 1.04 & $217.65^{*}$ & 0.0 \\
(depth 5-10cm) & W & 38 & 0.18 & 0.005 & & \\
Different soil depth & B & 1 & 0.024 & 0.024 & $0.7^{\text {n.s }}$ & 0.4 \\
$(0-5$ \& 5-10cm) & W & 78 & 2.64 & 0.034 & & \\
\hline
\end{tabular}

Note: $\mathrm{DF}=$ Degree of freedom; $\mathrm{SS}=$ Sum of squares of error; $\mathrm{MS}=$ Mean square; $\mathrm{F}=$ Value calculated by dividing MS source with MS error in SAS software; * = Significant in probability level of $5 \%$; B= Between Groups; W= Within Groups; sig = significant diffrence; $n . s=$ no significant.

\section{Conclusion}

According to results it can be concluded that the skidding causes to decrease organic matter and forest soil disturbance. Rutting and lack of herbaceous cover on skid trails (due to rainfall) causes to wash soil organic matter especially on slopes. Inaccessibility to organic matter causes to disturb sapling regeneration and herbaceous cover. In order to decrease damage to forest soil it is better that the skid trail is covered by vegetation foliage and wood debris. Moreover, it is recommended that the skid trails seeded after skidding operation. Moreover, in order to decrease disturbance of soil organic matter in forest ecosystem, Tite Pressure Control System (TPCS) can be used on skidders to reduce the pressure of wheels per unit area at minimum level.

\section{Acknowledgment}

The authors would like to thank the Shahid Beheshti University for laboratory support. Also, special acknowledgements go to Mr Habibi and Ahmadi for their technical support through out the course of this project.

\section{References}

Arocena, J. M. (2000). Cations in solution from forest soils subjected to forest floor removal and compaction treatments. For. Ecol. Manage., 133, 71-80. http://dx.doi.org/10.1016/S0378-1127(99)00299-6

Davis, S. (1992). Bulk density changes in two central Oregon soils following tractor logging and slash piling. Western J. Appl. For., 7, 86-88.

Demir, M., Makineci, E., \& Yilmaz, E. (2007). Harvesting impact on herbaceous understory, forest floor and top soil properties on skid road in a beech (Fagus orientalis Lipsky) stand. Journal of Environmental Biology, 28(2), 427-432.

Demir, M., Makineci, E., Comez, A., \& Yilmaz, E. (2010). Impacts of repeated timber skidding on the chemical properties of topsoil, herbaceous cover and forest floor in an eastern beech (Fagus orientalis Lipsky) stand. Journal of Environmental Biology, 31, 477-482.

Froehlich, H. A. (1979a). Soil compaction from logging equipment: effects on growth of young ponderosa pine. J. Soil and Water Conserv, 34, 276-278.

Greacan, E. L., \& Sands, R. (1980). Compaction of forest soils. Aust. J. Soil Res., 18, 163-189. http://dx.doi.org/10.1071/SR9800163

Hassan, A. E. (1978). Effect of mechanization on soils and forest regeneration. I. Coastal plain organic soil. pp. 1107- 1112. In Transactions of the Amer. Soc. Agric. Eng., 77-1571.

Hendrickson, O. Q., Chatarpaul, L., \& Burgess, D. (1989). Nutrient eyeling following whole-tree and conventional harvest in northern mixed forest. Can. J. For. Res., 19, 725-735. http://dx.doi.org/10.1139/x89-112

Holman, G. T., Knight, F. B., \& Struchtemeyer, R. A. (1978). The effects of mechanized harvesting on soil conditions in the spruce-fir region of north-central Maine. Life Sciences and Agric. Experiment Stn., University of Maine, Bulletin No. 751.

Johnson, J. A., Hillstrom, W. A., Miyata, E. S., \& Shetron, S. C. (1979). Strip selection method of mechanized 
thinning in northern hardwood pole size stands. Res. Note 27, Ford Forestry Centre, Michigan Tech. Univ.

Lenhard, R. J. (1986). Changes in void distribution and volume during compaction of forest soil. Soil Sci. Soc. Am. J., 50, 462-464. http://dx.doi.org/10.2136/sssaj1986.03615995005000020042x

Magnusson, W. E., De Lima, O. P., Reis., F. Q., Higuchi, N., \& Ramos, J. F. (1999). Logging activity and tree regeneration in an Amazon forest. For. Ecol. and Manag., 113, 67-74. http://dx.doi.org/10.1016/S0378-1127(98)00418-6

Mariani, L., Chang, S. X., \& Kabzems, R. (2006). Effects of tree harvesting, forest floor removal, and compaction on soil microbial biomass, microbial respiration, and $\mathrm{N}$ availability in boreal aspen forest in British Columbia. Soil Biol Biochem, 38, 1734-1744. http://dx.doi.org/10.1016/j.soilbio.2005.11.029

Matsuura, F., Hamada, Y., \& Shioiri, T. (1992). Efficient of synthesis of phytosiderophore, utilizing the fenyl group as the carboxyl synthom. Tetraherdon Letter, 33, 7917-7920. http://dx.doi.org/10.1016/S0040-4039(00)74778-2

Soane, B. D. (1990). The role of organic matter in soil compactibility: a review of some practical aspects. Soil \& Tillage Res., 16, 179-201. http://dx.doi.org/10.1016/0167-1987(90)90029-D

Williamson J. R., \& Neilsen, W. A. (2000). The Influence of Forest Site on Rate and Extent of Soil Compaction and Profile Disturbance of Skid Trails during Ground-Based Harvesting. Can. J. For. Res., 30(8), 1196-1205. http://dx.doi.org/10.1139/x00-041

Williamson, J. R., \& Neilsen, W. A. (2003). The effect of soil compaction, profile disturbance and fertilizer application on the growth of eucalyptus seedlings in two glasshouse studies. Soil Til l Res., 71, 95-107. http://dx.doi.org/10.1016/S0167-1987(03)00022-9

Zabowski, D., Skinner, M. F., \& Rygiewicz, P. T. (1994). Timber harvesting and long-term productivity: weathering processes and soil disturbance. For. Ecol. Manage., 66, 55-68. http://dx.doi.org/10.1016/0378-1127(94)90148-1 